\title{
[ 286.]
}

XXXI. An Account of fome artificial Caverns in'the Neigbbourbood of Bombay: By Mri. William Hunter, Surgeon in the Eaft Indies.

$$
\text { Read July i, } 1784 \text {. }
$$

$N$ different parts of the ifland of- Salfette, and in the neigh1.: bourliood of that of Bombay, we meet with fore moft ftupendous monuments of human labour and ingenuity; which would be matter of admiration in any part of the world, but? muft aftonifh us ftill more, when we find them in a country remarkable for the indolence of its prefent inhabitants. Thefe are a fet of enormous excavations, all of which are made in folid rocks, and decorated with a variety of figures, moft curioully cut from the fame fubftance with the caverns themfelves. That which has principally attracted the attention of travellers is on the fmall ifiand of Elephanta, fituated in the eaft fide of the harbour of Bombay. This-ifland runs to a confiderable height in the middle, and has a flope to the north and fouth, in which direction is its greateft length. Near the fouth end is the figure of an elephant, rudely cut in ftone, from which the ifland has its name. The length of the body is twelve feet, the height about eight. The trunk is rolled up in a fpiral form, and pretty well cut; the legs are thapelefs maffes of matter, out of all proportion too large, and feem intended merely as pillars to fupport the fabric. We muft look in the fame light on the tail, which 
Mr. Hunter's Account of artificial Caverns, \&c.

is maffy, and reaches to the ground; and on a pillar, which is placed under the pofterior part of the belly. On the back are the remains of fomething that is faid to have formerly. reprefented a young elephant, though no traces of fuch a refemblance are now to.be found. The whole has been formed from one piece of ftone; but the body is now. fplit in two, and there are:vifible marks of its having been done by gun-powder. About half a mile to the northward, you are conducted by a pretty, fteep afcent up the fide of a rock, to the door of the cave, which enters. from the North. By it you are led firft of all into a feerandah, or piazza, which extends from eaft to weft fixty feet; its breadth from.north to fouth is,fixteen feet. In the weft end is a human figure with eight arms, four on each fide, united at the fhoulder, one behind another. On the right the foremoft arm paftes acrofs the body, and is applied to the oppofite fide, at that part where the iuhabitants of the country ufually wear their crees or dagger, as if about to draw it. The fecond is thrown cut from the body, and the fore-arm has been bent, fo as to come before the: breat,; but is broken off a very little way beyond the elbow. The humerus of the third is parallel to the former, but the fore-arm entirely broken off. The fort-arm of the fourth is, bent upwards. but broken off near the writt. The two firft arms on the left fide are gently bent, and hang downwards: the third fupports a fmall female figure, and the fourth is extended above the head, to fupport an irregular body fomething like the folds of a hangiug cotlected together. The right thigh is bent outwards, almoft at right angles to the body, but broken off near the kuce. The left is broken off clole to the hip. This figure is furrounded: by a number of finaller ones in various atitudes. In the eat end is another human figure, which is now rothing more than a buft, as it only extends to the waift, and the arms are wanting. This laft circumftance however is the effect of violence, for the 
$238 M r$. Hunter's Account of artificial Caverns in arms hear evident marks of mutilation. Both thefe figures, and molt of thofe which are to be defcribed, wear on their heads a kind of helmet, the body of which teems to be compofed" of a foft fubftance applied very clofely to the head, fomething in form of a turban, but of a more pyramidal thape than thofe worn by the inhabitants at prefent, and marked with inequalities which give it the appearance of a quilted ftuff. In the front is a plate much like that of a grenadier's cap; and on each fide appears part of another plate, which is placed on the back part of the heal, and projęts from behind the ears. It is ribbed like a fcallop hell, and a good deal refembles (in figure though not in fituation) the ruff formerly worn in England. Some of the figures in the fouth end of the cave have the back of their heads turned towards the fpectator, fo as to afcertain the form of this plate exactly, which is not the cafe with thofe which prefent their faces. For though all thefe ftatues are as round and prominent as the life, yet none of them are entirely detached from the fides of the rock. The two figures juft now defcribed have large mafiy ear-rings, and below thefe appear a few ringlets of hair which.fpread upon the fhoulder: The urder lip of thefe, as well as of the other figures, is remarkably thick.

THE body of the cave is furrounded on every fide by feerandabs fimilar to the former. The dimenfions of the cave and feerandahs are as follows:

Length of the cave from north to fouth Breadth of the fouth feerandah, including the niches

which contain certain figures to be after defcribed Breadth of the North feerandah Weft 90 feet

Eaft

Breadth of the cave from Eaft to Weft

24

I 6

16

16

78

Whence 
whence the whole length, including the feerandais is $\mathrm{r}_{3} \mathrm{~J}$ feet, and the entire breadth iro.

THE roof is fupported by four rows of pillars placed at the diftance of fifteen feet from each other. The bafe of each pillar is a.fquare parallelopiped, three feet three inches thick, and five feet nine inches in height : on this ftands a round column, five feet high, which tapers pretty faft towards the top. It is terminated by a ring, one foot and an half in thicknefs, which projects exactly like the cordon in a piece of fortification, and has been compared, not improperly, to a round cuhion preffed flat by the weight of the fuperincumbent rock. Above this is another fquare parallelopiped, one foct high, and on the top of it a plate, nine inches thick, which projects to eaft and.weft two feet and an half beyond the top of the, pillar, having its ends floped, and cut into a moulding. Its breadth from north to fouth is the fame with that of the pillar. Above all, there runs from eaft to weft, over the top of the pillars, a ridge cut out from the rock, refembling a beam, about one foot in thicknefș. From thefe data, we find the whole height of the cave to be fifteen feet. The column, cordon, and upper parallelopiped (which two laft form the capital) are finely fluted, and on each corner of the bafe, where it projects beyond the column, is placed a fmall figure in a fitting pofture.

IN the wert end of this cave is a chamber, twenty feet fquare, with four doors, and within it is fomething like a fmall maufoleum. This has probably been the place peculiarly confecrated to religious worhip, the fanctum fanctorum of the cave. On each fide of every door is a gigantic figure, in all eight. Their heads are decorated in much the fame manner as before defcribed; they have chains round their necks, and ear-rings of an enormous fize. The moft entire is on the eaft fide of the fouth door. Its whole height is about thirteen feet and an half. $\mathrm{He}$ VoL. VII. 
290 Mr. Hunter's Account of artificial Caverns in

refts on the right leg, and the knee of the left is a little bent. The right humerus hangs downwards, parallel to the body, and the fore-arm is bent in fuch a mamner that the hand is oppofite to the navel: the palm is turned upwards, and fuftains a globe; and the fingers are bent a little backwards at their joining with the metacarpus, in a manner that admirably reprefents, or, to fpeak more properly, makes the fpectator almoft feel, the weight of the body which they fupport. A belt is paffed round the body at the navel, and from the left fide of this hangs a Arap, joining with, and fupporting a garment, which firft appears at the right hip, paffes over the thighs, under the genitals, which it leaves uncovered, and is tied in a large knot on the outfide of the left thigh. From this knot, it is reverted over that thigh and cruffes the other part of the fame garment, from whence the end hangs loofe between the legs. The left hand refts on the larger knot of this garment. The left thigh and knee are in particular well executed. The patella is diftinetly formed, and you can clearly perceive the fwelling of the vafti mufcles, efpecially the vaftus internus. The legs are not handfome, as they taper from the knee and have little or no calf; however, they much refemble thofe generally met with among the inhabitanes of this country.

IN the north end of the wert feerandah is a very extraordinary figure, with eight arms, his body inclined very much to the left, his legs folded under him, but too much mutilated to diftinguith their real pofition. Two of the arms fupport a curtain or canopy over his head. On this canopy fit a number of figures in the attitude of devotion. One of the right hand's holds a fword of juftice, and in one of the left is a pedeftal, on which ftands a fmall figure with his back turned to the large one, and inclined fo much backwards that the head, when entire, mutt have hung very low; but that is now broke off, and 
the other parts of the figure are greatly mutilated. From thefe two circumftances many travcllers have fuppofed the large ftatue to reprefent Solomon in the act of dividing the child; an idea fo sepugnant to all probability, that I fhould not have thought it worth mentioning had I not heard and feen it afferted with a great degree of confidence. Another of the left hands holds a bell, which is known to be an inftrument conftantly ufed in the religious ceremonies of the Gentoos. 'The arms and hands of the large figure, which are entire, and fix in number, are exceedingly well executed; the other two are broken off.

We have already feen that the people, whoever they were, who carved thefe ftatues have accurately obferved and ex. preffed fuccersfully the form of the limbs, and the alterations that undergoes from mufcular action or external impulfe. But in the oppofite end of this feerandah is a group of figures which thews them to have poffeffed a much more difficult part of the ftatuary's art, I mean that which reprefents the effects of mental fenfations on the human countenance. The three principal figures which compofe this group are two men, and a woman placed between them, all at full length and in a ftanding porture. One of the men refts his hand on the Moulder of the woman; who feems ftudioufly to turn away from him; the other man, from his air, has the appearance of fuperior rank, and, if we may judge from the refemblance of his drefs to that worn by the Bramins at prefent, belongs to that facred order. An air of dejection is vifible in every one of thefe figures; their, heads are declined a little from the perpendicular attitude, and every feature is expreffive of grief, not indeed of any violent agitation, but of a fettled, deep rooted concern.

BuT the moft remarkable figure of all is in the fouth feerandab, directly facing the main entrance of the cave. It is an

$$
\mathrm{P} \mathrm{p} 2 \text { enormolis }
$$


$292 M i$. Hun'ter's Account of artificial Caverns in

enormous buft, with four heads joined behind the ears; one of which faces prefents itfelf directly in front, two more are feen in profile, and the fourth does not appear, being hid behind the firft. The firft face meafures four feet from the top of the brow (where the ufual ornament of the head begins) to the bottom of the under lip: the nofe is about one foot and an half in length; the whole length of the face is four feet and an half; the breadth from the ear to the middle of the nofe, three feet four inches. The breadth of the whole figure between the thoulders is about twenty feet. This face has a drowfy but placid appearance, That on the left (of the fpectator who faces it): has the eyebrows contrakted, the $\mathrm{k}$ in of the nofe drawn upwards and the alce nafi diftended, expreffing contempt mixed with indignation. The mouth is furnifhed with whifkers; the tongue is thruft out between the teeth, and the whole features are in fome degree monftrous. There are four hands, one on each fide, and two others half way between the former and the middle of the figure. The outermoft right hand (that moft to the left of the fpectator) fupports a large hooded fuake; the middle finger is not quite entire, but mult have been about three feet and an half in length. The thicknefs of the fnake is about a foot. The inner band on this fide is entirely broken off, but appears to have held a fnake of the fame kind with the former. The inner left hands fupports a body of an oblate fpheroidal form with a conical excrefcence at the upper part and fcaly like the fquill or filly root, of of fuch a fize as to fill the palm of the hand compleatly. The rimaining face has a more pleafing afpect than the laft; the under lips of both are remarkably thick. The outer left hand is refted on the fhoulder, with the palm turned inwards, and holds an irregular body like a bunch of flowers. May we not afcribe the difference which is fo remarkable in the afpect of the two laft meritioned faces to the nature of the objeats which are held 
in the two hands, directly in view of thofe faces? All the heads have very large ear-rings, and much the fame ornaments with thote before defcribed.

$\mathrm{O}_{\mathrm{N}}$ the eaft end of the fame wall is an Amazon; the left breaft, which is the only one, is very large and globular; and it plainly appears that there has never been any other. The right arm refts on the head of a bull; the-left hangs down, and takes hold of fomething which is fo much mutilated that we cannot difcover what it has been meant to reprefent. Behind thefe are two other arms; the right fupports a fnake of the kind beforementioned, and in the left the holds a fmall thield, grafping 'it by that part which is meant for the infertion of the arm. The fhield is round, and regularly convex on the outfide, which the ftatue turns towards herfelf, holding it nearly on a level with the houlder. She has double bracelets on her two left hands, and a ring on each finger; on the right are fingle bracelets, and a ring only on the little finger. She leans, as beforementioned, to the right fide, which ought to make the left hip project a little; but that projection is greatly exaggerated in the reprefentation, which makes it appear diftorted. The figure is furrounded. with many fmaller ones, both human and animal, in various poftures.

$\mathrm{O}_{N}$ the left fide of the great figure with three faces is a male ftatue at full length; his left hand leaning, or rather preffing on the head of a dwarf; who, by the pofition of his body, and expreffion of his countenance, feems to experience great torture. Thefe dwarfs are figures of a monftrous form that frequently occur in this and in fome of the other caves. They have heads of an enormous fize, with very thort necks. Their breaft is contracted, but the belly large, prominent, and much longer than it ought to be in proportion to the other parts. The legs and thighs 
294 NI: Hunter's Account of artificial Caverns in

thighs are very fmal, bearing no proportion, either in length or thicknefs, to the reft of the figure. They are commonly placed, as in the inftance before us, clofe to a large ftatue who leans on them, and fometimes appears to give them very great pain. The dwarf we have been now fpeaking of holds in his right hand a fnake, twifted in a variety of folds. The large figure, from the knotted ftring over his left houlder and breaft, appears to be of the order of Bramins. A number of figures round him are prefenting offerings, one of which is plainly a filh. One figure is kneeling at the foot of the large one, with his eyes turned upwards. A fmall figure on the right of the Bramin has a knife by his fide, very diftinctly made. The ribbed plate on the back of the head in this figure is of a circular form. On the left, in the fame niche, is a reprefentation common enough in this cave, that is, one figure fitting with his legs over the Mhoulders of another.

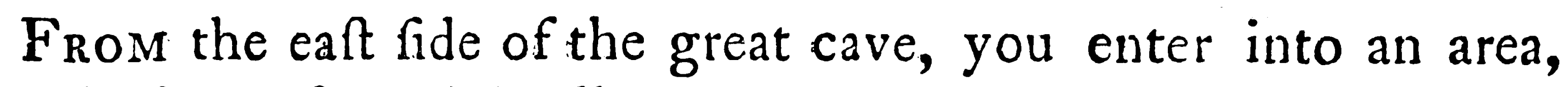
in which are feveral fmaller apartments. On the fouth wall of this area is a gigantic figure, who refts his left arm on the head of a dwarf, his right fupports a hooded fnake. He has a broad fword hung at his left fide, by that belt, or garment, which in molt of the other figures paftes over the thighs in the manner before defcribed, only in this figure it defcends towards the right thigh inftead of the left. He has four hands, the backmoft left one fupports a fmall human figure; one of the right hands is broken off entirely. The ornament on the head of the dwarf refembles a curhion, and above that is placed a folid body like the round ring of one of the pillars with part of the column, and on this the giant refts his hand. Round the body of the dwarf is twifted a fnake, the head of which hangs down below the left hand of the dwarf. The length of this area is fiftyeight feet, and at each end is a fmall apartment, the floors of

which 
which are covered with water. That on the weft is decorated with nany figures, two of which refemble fome of thofe monftrous Deities that are adored by the Gentoos at this day. That in the eaft end is entirely without ornament. Oppofite to the middle of the area is a chamber with a fmall maufoleum in it.

$\mathrm{F}_{\mathrm{R}} \mathrm{OM}$ the welt fide of the great cave you enter into another fquare area, open above, by means of a cut made upwards through the whole thicknefs of the rock, about forty or fifty feet. In this are two fmall apartments, which have nothing remarkable in them; and an irregular cavern, full of water, which reaches inwards, below the bottom of the cave, fo far, that the eye cannot difcover where it terminates.

THE whole cave and the apartments adjoining to it are cut out of a folid rock of a very hard confiftence. The figures have fuffered nothing from time, for the furfaces of them all are fmooth and well defined; but all the mutilations, which they have fuftained proceed from the brutal violence of barbarians who delight in mifchief and are enemies to tafte and fcience.

THE molt remarkable, next to that latt defcribed, is

The cave at Ambola, a village about feven miles diftant from Tannah, in the ifland of Salfette. The cave lies a mile to the weftward of this place: The principal entry is from the weft; it is about eight feet wide, and covered at the beginning with an arch, formed by the trunk of a tree fallen acrofs, the head of which has taken root. From the middle of it, fome large fprouts have grown up, forming a new tree. From this the paffage colitinues of the fame breadth for about thirty fett, when it is extended to three times its former breadth. You advance about twelve feet more, ai:d che a come to a flight of feven fteps, which leads down iuto the cave. The paffage till you come to thefe fteps is open above. It he great gate is about twenty feet high, including the height of the fteps, and the cheeks of it ap- 
296 Mi. Hunter's Accownt of arificial Caverns in pear to have been fluted columns, but are now entirely defaced. By this gate you enter into an antichamber, which has at each cnd a fmall feerandah, feparated from the reft of the place by a row of three pillars. Directly facing you is the door of the cave, on each fide of which is a figure, which we can juft diftinguith to have been human, fo much have they fuffered from the ravages of time. The head of that on the left is fo defaced that its form and drefs are quite indiftinguinhable; only the ftumps of boilh arms are left, but from the pofition of thefe Atumps with regard to the body, and ftill more from the analogy of other figures which are more entire, it appears, that the left arm has been in a depending pofture, with the elbow bent. The figure on the right is much in the fame pofture, and the left arm'more entire; the bead is covered with fomething that has the appearance of a helmet. The great cave, into which you enter by this gate, is a fquare of eighty-eight feet, within which are contained two fmaller fquares, concentric to the larger; the outer, formed by pillars placed parallel to the fides of the great fquare at the diftance of fifteen feet from the outer wall of the cave. Each row confifts of fix pillars including the end ones, in all twenty. The pillars are about thirteen or fourteen feet high, and of the fame form with thofe in the cave at Elephanta. In the centre of this fquare, alfo at the diftance of fifteen feet, is the innermoft of all, inclofed by a folid wall, and having a door in the middle of each fide. This chamber, as well as all the other parts of the cave, is cut from the folid rock. Within is a cubical mafs, which appears to have been the pedeftal of fome Gentoo Deity, as this place is 'ftill confecrated to their worhip. On the top of this pedeftal, is erected a wooden frame, on which hangs a bell, ufed by the Gentoos in their religious ceremonies. The doors are formed with regular frames and cornices, and have been highly ornamented. On each fide of thefe doors have 
been groups of figures, about three feet high, forme of them evidently montrous, but all of them noiv greatly defaced.

IN the eaft end of the cave are three doors, by which you enter into another apartment. The middle door leads into the body of this apartment, and the other two enter into two feerandahs; feparated from the place itfelf by rows of pillars, fuch as before defrribed. On each fide of the midlde door within this apartment is a gigantic figure, attended by finaller ones. Thát on the lefft hand of the fpectator who faces thein is entire in all the parts above the hip; except the two hands, which are both broken off: He is of a robuft make, well proportioned, and finithed in a mafterly manner. The face is broad, with a fpa eious forehead, the cheeks are full, and the whole countenance has an air of ferenity, but nothing lively or expreffive of acutenefs or penetration. This figure has no beard, nor have any of the others except one, which is in a fmall group, over the large figures we are now defcribing. The hair of this gigantic ftatue is burhy, and formed into curls, which hang down upon the neck; there is a pyramidal ornament upon the crown of the head. The ears are pierced; and have large jewels fufpended from them. Over the left fhoulder is thrown a chain, which defcends acrofs the body, as far as the right hip. Round the waif about the top of the bones which form the pelvis another chain is paffed, from the right fide of which hang two fmaller chains that are foon loft in a garment, which defcends in a flanting direction from the right fide, covers that thigh, and the lower part of the left, but yet feems to leave the genitals bare. The right arm is bent up towards the top of the fhoulder, probably to hold the garment beforementioned. The left arm hang; down, nearly ftraight, and almoft parallel to the body. Th: legs are miferably defaced, fo that we can juft difcover the right foot to have been advanced before the lett. A chain goes round Vol. VII. 
$298 M r$. HUN ter's Account of artificial Caverns in

each arm, about the infertion of the deltoid mufcle, and has on the outfide the figure of a face, which is probably the place where it is faftened. On the left of this ttatue are two fmaller ligures, one of which is higher by the head than the other, and Itands behind him. They certainly reprefent children, from the fize of the head, which is very large in proportion to the body. Both thefe figures have rings in their ears, and their hair has much the appearance of a wig. The larger has the right hand raifed as high as the top of his thoulder, and refts it on the head of the other, who appears to ftretch out his neck, and look forward with great eagernefs at fome diftant object. The body of this one below the neck is entirely demolihed.

THE figure on the other, fide of the doors is of the fame exquifite workmanhip with the former. The right arm is in the fame pofture as that laft mentioned, and fufpends a garment which is very diftinctly reprefented. It covers both thighs and all the parts from the top of the os ilium, to, within a hand's breadth of the knee. It is tied in a knot on the left hip, from which it hangs down in loofe folds. As far as we cain judge from what remains of the legs, the left is advanced one ftep forwards. The left arm refts on the head of one of thofe dwarfs before defcribed, who holds in his right hand fomething like a fnake, and with the left fupports fome animal the fpecies of which we cannot determine. Over the top of the door are feveral groups of fmall figures, admirably executed.

THIs apartment is about thirty feet long, and has a door in the eaft end which leads into two fmall caves, in which there is nothing remarkable. The two doors of this apartment, the eaft and weft ones of the fmall fquare in the middle of the great cave, an the two firt defcribed which form the principal entrance, are all in one ftraight line, in length about one hundred and thirty feet. 
From the fouth fide of the cave you enter into an irregular paffage in the rock which afcends by a gentle flope towards a. hole that is juft fufficient to let a man of a flender make creep through, and leads into a paffage between two pretty high rocks. But another branch of the fame fubterraneous cavern ftrikes off to the right, and, after making a curvature, which prevents one at firft entering it from feeing the end, leads you to the door of a fmall regular apartment, the floor of which is covered, about three inches deep, with very clear water. This apartment is divided into two, and in the backmoft of thefe is a Gentoo Deity.

Th $\mathrm{c}$.whole cave is cut out of the rock, in the fame manner with that at Elephanta, but the ftone is of a much fofter quality, fo that, although the figures here bear fewer marks of violence than the others, they have fuffered much more from the hand of time, infomuch that fome of them are more than half mouldered away. The two large figures in the fmaller apartment, though evidently a continuation of the fame rocky fubftance, feem to be an exception to this general obfervation; for, though fome of their limbs are broken off, the parts that remain have a fmooth furface, and are harder than moft other parts of the cave.

$\mathrm{BuT}$ the moft numerous collection of thefe caves is at $\mathrm{C}_{\mathrm{A}}$ NARA, a place within about ten miles of Tannah, and more to the northward than Ambola. Here a very large hill is almont totally furrounded with thefe excavations of various forms and fizes, but none of them are finifhed in fuch an elaborate way, or decorated with fo numerous figures as thofe before defcribed. I thall therefore not enter into a tedious defcription of each particular cave, but only mention fome remarkable circumftances in which thefe differ from the others.

$$
\text { Qq }{ }^{2} \quad T_{H E}
$$


THE pillars we meet with here are rudely hewn, of irregular thapes, and without much uniformity one with another. 'Many, of thefe caves are more than double the height of thofe at Elephanta or Ambola; and fome of them have fquare holes at equal heights on oppofite fides of the walls, as if intended for beams to fupport a floor, which idea is confirmed by their having windows at that height. Many of thefe caves are very fmall, but others do not yield in extent to thofe before defcribed, and are furnifhed with veftibules, from which you: enter into the body of the place. One of thefe veftibules has, at each end, a Itatue of a much larger fize than any of thofe before defcribed, except.the buft with three heads in the cave at Elephanta. They ftand in two niches, and by that means are more nearly detached from the rock, out of which they are cut, than any of, the others. The ftatues are at full length, in height about twenty. feet, and in every refpect well proportioned. The heads are bare, and the hair formed into loofe curls. In the caves before defcribed we hardly meet with a capital figure that is not furrounded by a numerous group of fmaller ones; but here the cafe is otherwife. It is alfo to be obferved that we do not find in thefe caves any of the monftrous figures which occur now and then at Ambola, but much more frequently at Elephanta. On the wall of one of the caves is a pretty long infeription, very entire; from which, it is reafonable to fuppofe; fome curious,information might be collected, with regard to the antiquity and original defign of thefe caves. All I could learn concerning it was that it is in the Gentoo language, and contains benedictions. on thofe who Ahall come to this place to worhip. If this is true, which I do not give as a certain fact, it determines at once the defign for which thefe immenfe works were undertaken, in a mauner that is very probable, from the many figures which refemble 
refemble the Gentoo Deities, and: ftill more' from the cave at Ambola being confecrated to their religious worfhip even at this time.

$T_{H E}$ antiquity of all the caves, is undoubtedly very remote. None of the inhabitants have any tradition, relating to their origin ; : and indeed many circumftances, would lead us to fuppofe that they have been conftrukted by at very' different race 'of men from thofe who now inhabit this country. In the firft place, the oprefent inhabitants are extremely indolent, and 'very.'unlikely' to sexecute a work of fuch enormous labour. Secondly, whentthey makeiany attempts at fculpture, their performances are almolt all of the monftrous kind; and deftitute of grace or proportion; whereas the imajority of the figures now defcribed are natural, and even moft of thofe which are monftroushave limbs elegantly proportioned: It is farther natural to fuppore that thofe artifts would take the models of their work from among themfelves; and the figures are very far from refembling the prefent race of Indians. The general form of the body is more robutt and mufcular; but the moft remarkable difference lies in the countenance, which is broad and full; the nofe flat; the lips, particularly the under one, remarkably thick; and the whole combination of features of a drowfy appearance, very unlike that acute and fprightly look which diftinguifhes the natives of Hindoftan. And the kind of features here defcribed are fo univerfally found in all the figures, that they cannot be afcribed to any fortuitous circumftance. An argument againt what has been faid may be taken from the infoription mentioned above, which is faid to be in the language fpoken by the Gentcos at this day; but, allowing this to be true, it is not improbable that the insfcription may be of much later origin than the cave itfelf. From the fimplicity which reigns through the whole of the cares at Canara, and the total want of thofe monitrous figures which wo 
$302 M r$. Hunter's Account of artificial Caverns, \&c.

meet with in the others; I think it probable that the former are the moft ancient of the whole, and that the others have not been confructed till both the tafte and the mythology of the people began to be corrupted.

From confidering the incredible labour that muft have been employed in cutting thefe caves in a hard and folid rock, the idea has been fuggefted, that it may, at the time the work was performed, have been of a fofter confiftence, and been afterwards hardened by expofure to the air ; and indeed this conjecture appears, from the many fimilar inftances known to every one, to carry with it a great degree of probability. It would not be difficult to put this to the teft of experiment, by digging in fome of the adjacent parts; and, as the enquiry is curious, the attempt would well deferve the attention of any one who thould have leifure and opportunity to profecute the fubject. 